\title{
GREENHOUSE GAS DYNAMICS OF AN INCREASED USE OF WOOD IN BUILDINGS IN SWITZERLAND
}

\author{
FRANK WERNER ${ }^{1}$, RUEDI TAVERNA ${ }^{2}$, PETER HOFER ${ }^{2}$ and KLAUS RICHTER ${ }^{3}$ \\ ${ }^{1}$ Environment and Development, Waffenplatzstrasse 89, CH-8002 Zurich \\ E-mail: frank.werner@gmx.ch \\ ${ }^{2}$ GEO Partner AG, Baumacherstrasse 24, CH-8050 Zurich \\ E-mail:hofer@geopartner.ch \\ ${ }^{3}$ Swiss Federal Laboratories for Materials Testing and Research (Empa), Ueberlandstrasse 129, \\ CH-8600 Duebendorf \\ E-mail: klaus.richter@empa.ch
}

\begin{abstract}
Long-living wood products contribute to the mitigation of climate change in many ways. They act as a carbon pool during their service life, as they withdraw $\mathrm{CO}_{2}$ from its natural cycle. After their service life, they can substitute for fossil fuels if they are incinerated in adequate furnaces. Furthermore, wood products can substitute for more energy-intense products made of 'conventional' materials. This paper quantifies the substitution and pool effects of an increased use of wood in the building sector in Switzerland for the years 2000-2130. Life cycle data on greenhouse gas (GHG) emissions of 12 wood products and their substitutes are used as proxies for relevant building products; this data is linked to the forecasted wood flows for each group of building products in a cohort-model. For the political assessment, GHG effects occurring abroad and in Switzerland are distinguished. The results show that the pool effect of an increased use of long-living wood products is of minor importance, whereas the energetic and material substitution effects are much more relevant, especially on a long-term. For construction products, the Swiss share of the GHG effect related to the material substitution is relatively high, as mainly nationally produced materials are substituted for. For interior products, the Swiss share of the GHG effect related to the material substitution is rather small because mainly imports are substituted for. The results must be considered as rough estimates. Nonetheless, these calculations show that an increased use of wood in the building sector is a valid and valuable option for the mitigation of greenhouse gas emissions and for reaching GHG emission targets in a mid- to long-term. Still, the pool and substitution capacity of an increased use of wood is relatively small compared to the overall GHG emissions of Switzerland.
\end{abstract}

\section{Introduction}

Wood as a $\mathrm{CO}_{2}$-neutral natural resource and energy carrier plays an important role in the discussion on the mitigation of climate change. Long-living wood products in particular can contribute to the mitigation of climate change in many ways (Fischlin, 1996; IPCC, 1996, 2000; Matthews et al., 1996; Niles and Schwarze, 2001; Skog and Nicholson, 1998). On the other hand, wood products with long service life act as a carbon pool during their service life, as they withdraw $\mathrm{CO}_{2}$ from its natural cycle. After service life, they can substitute for fossil fuels if they are incinerated 
in adequate installations; on the other hand, wood products can substitute for more energy-intense products made out of 'conventional' materials.

The Swiss Federal Council and the Swiss Parliament have committed to an active climate policy by signing and ratifying the Kyoto protocol. Knowledge about the effectiveness of measures to mitigate climate change is an important basis to achieve this commitment.

Much work has been done on international level to develop an adequate procedure for the accounting of long-living wood products in national greenhouse gas (GHG) inventories (IPCC, 2003; SBSTA/UNFCCC, 2001, 2003a,b,c; Hashimoto et al., 2002; IPCC, 1998; Marland and Marland, 2003; Winjum et al., 1997; IPCC, 1997a,b,c; UNFCCC/TP, 2003; Ford-Robertson, 2003; Lim et al., 1999). Several studies have tried to quantify the wood flows and pools for some countries, and specifically for their building sector (e.g., Müller, 1998; Pingoud et al., 2001 and literature stated therein). Further research has targeted energy consumption and fossil carbon dioxide emissions of wood products (Pingoud and Lehtilä, 2002), sometimes even relating them to 'conventional' reference products (Buchanan and Levine, 1999; Sedjo, 2002; Buchanan and Honey, 1994; Koch, 1992; Marcea and Lau, 1992; Suzuki et al., 1995 and the life cycle assessment (LCA)-based literature referred to below). Only estimates exist about the GHG relevance of an increased use of different wood products and the ways this increased use impacts climate change in a dynamic perspective, i.e. pools, production emissions as well as material and energy substitution. This study fills this gap.

The study emphasises the increased use of wood in the building sector, as this usage induces the most significant GHG effects compared to the GHG flows related to the use of paper or other wooden products (Hofer et al., 2001). The calculations are based on a 'realistic' scenario of future wood consumption in the building sector in Switzerland. For the calculations of the product-group-specific GHG effects, life cycle data on GHG emissions of about 12 wood products and their functionally equivalent substitutes are used as proxies for the most important groups of building products used for construction and for interior works. This data is linked to the forecasted wood flows for each group of building products in a cohort-model on a spreadsheet basis.

The investigation concentrates on the product-specific effects within the technosphere, where especially the substitution effects are hardly quantified (Matthews et al., 1996); it disregards the well-investigated carbon cycle in the forest (see e.g. Karjalainen, 1996; Marland and Marland, 1992; Matthews et al., 1996; Sedjo, 1989; Thompson and Matthews, 1989) as well as the potential use of harvesting residues as substitutes for fossil fuels. Nonetheless, some theses are presented about the relationship between the two pools forest and long-living wood products and how the overall results could be affected if the forest carbon pool was taken into account. This relationship will be studied in-depth in a further research project where the data of the two subsystems will be combined to depict the GHG effects of the complete forest wood chain (see also Liski et al., 2001). 


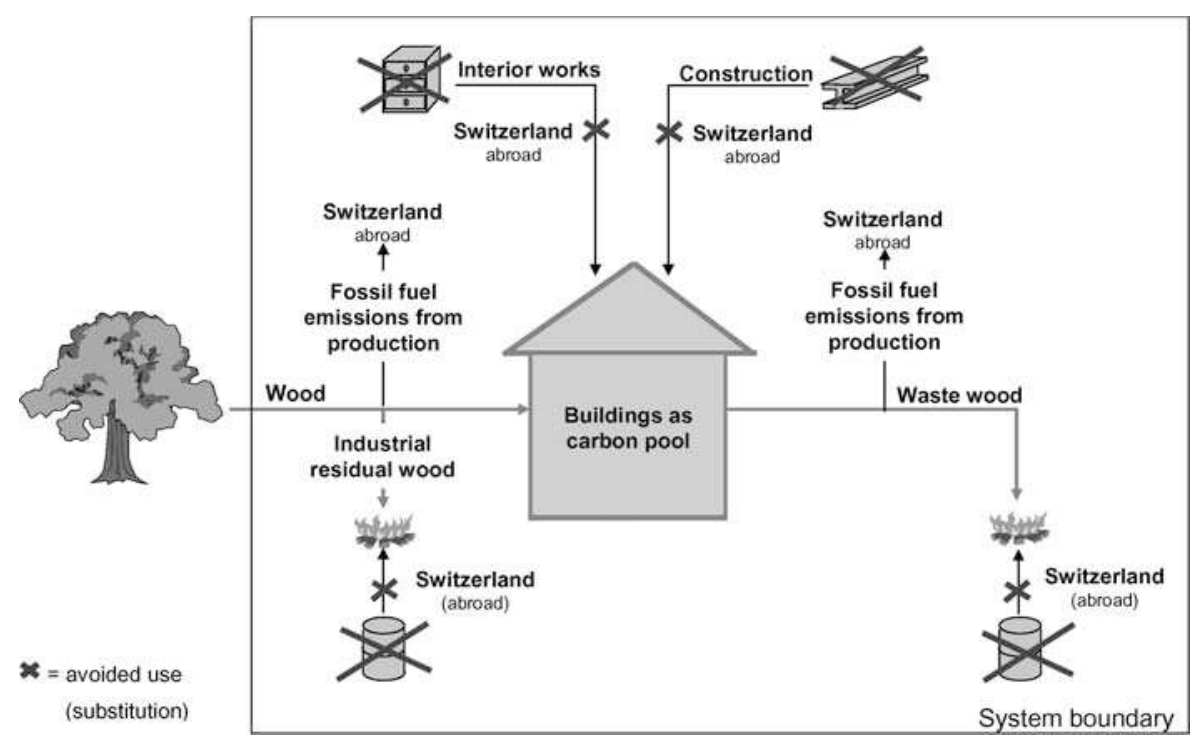

Figure 1. System boundaries of the building stock and its respective GHG effects.

\section{Model Structure, Data, Assumptions}

\subsection{SYSTEM BOUNDARIES}

Figure 1 illustrates the investigated system with its GHG effects. It covers:

- roundwood as model input (harvesting residues are excluded);

- the building stock as a carbon pool;

- emissions of 'fossil' $\mathrm{CO}_{2}$ related to the production and disposal of wood products used in construction and interior works;

- the avoided emission of 'fossil' $\mathrm{CO}_{2}$ related to the production and disposal of the 'conventional' products the wood products are substituting for (leading to material substitution effects);

- the energetic substitution effects of a (hypothetically complete) energetic use of

(a) industrial residual wood

(b) post-consumer waste wood.

Post-consumer wood could also be landfilled. Landfills might form a nearly permanent sink for some wood products (Micales and Skog, 1997). As Swiss legislation prohibits the landfilling of burnable waste, post-consumer waste wood combustion in suitable incinerators is assumed.

As mentioned above, the GHG effects in the forest due to an increased use of wood has been excluded from the calculations. 
For the political assessment, GHG effects occurring abroad and GHG effects in Switzerland are distinguished.

\subsection{SCENARIO DEVELOPMENT OF THE FUTURE USE OF WOOD}

For the baseline scenario, the following assumptions are made:

- Growth rate of the building sector economy of $1 \%$ per year ("business as usual');

- Stable wood consumption of the building sector, i.e. a slightly decreasing market share of wood products;

- current import-export patterns.

The scenario of a future increased use of wood in the building sector is based on the following assumptions:

- Growth rate of the building sector economy of $1 \%$ per year;

- Increase of the market share of wood products of $2 \%$ every 10 years;

- Constantly high use of wood of $+0.81 \mathrm{Mio}^{3}$ additional wood after the year 2030;

- Logistic growth curve of the annual wood flows to show a more realistic behaviour;

- Current import-export patterns for all non-wood products (including additives, fuels, etc.);

- All the additional wood is harvested and processed in Switzerland (as a maximal scenario).

Table I shows the wood use in the year 2030 that results from the above assumptions compared to the current wood use. Total annual wood consumption in constructions and buildings rises from $2.73 \mathrm{Mio} \mathrm{m}^{3} /$ annum in the year 2000 up to

TABLE I

Assumed additional annual wood flows from the year 2030 onward

\begin{tabular}{|c|c|c|c|c|c|c|}
\hline \multirow[b]{2}{*}{$\begin{array}{l}\text { Wood } \\
\text { consumption }\end{array}$} & \multicolumn{2}{|c|}{ Current use } & \multicolumn{2}{|c|}{ Optimistic scenario } & \multicolumn{2}{|c|}{ Difference } \\
\hline & 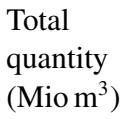 & $\begin{array}{l}\text { Quantity per } \\
\text { capita } \\
\text { (kg/cap.* annum) }\end{array}$ & $\begin{array}{l}\text { Total } \\
\text { quantity } \\
\left(\text { Mio m }^{3}\right)\end{array}$ & $\begin{array}{l}\text { Quantity per } \\
\text { capita } \\
\text { (kg/cap.* annum) }\end{array}$ & $\begin{array}{l}\text { Total } \\
\text { quantity } \\
\left(\text { Mio m }^{3}\right)\end{array}$ & $\begin{array}{l}\text { Quantity per } \\
\text { capita } \\
\text { (kg/cap.* annum) }\end{array}$ \\
\hline $\begin{array}{l}\text { Construction } \\
\text { wood }\end{array}$ & 1.05 & 75 & 1.36 & 97 & 0.31 & 22 \\
\hline $\begin{array}{l}\text { Wood for } \\
\text { interior works }\end{array}$ & 0.77 & 55 & 1.06 & 76 & 0.29 & 21 \\
\hline Residual wood & 0.91 & 65 & 1.12 & 80 & 0.21 & 15 \\
\hline Total & 2.73 & 195.0 & 3.54 & 253 & 0.81 & 58 \\
\hline
\end{tabular}



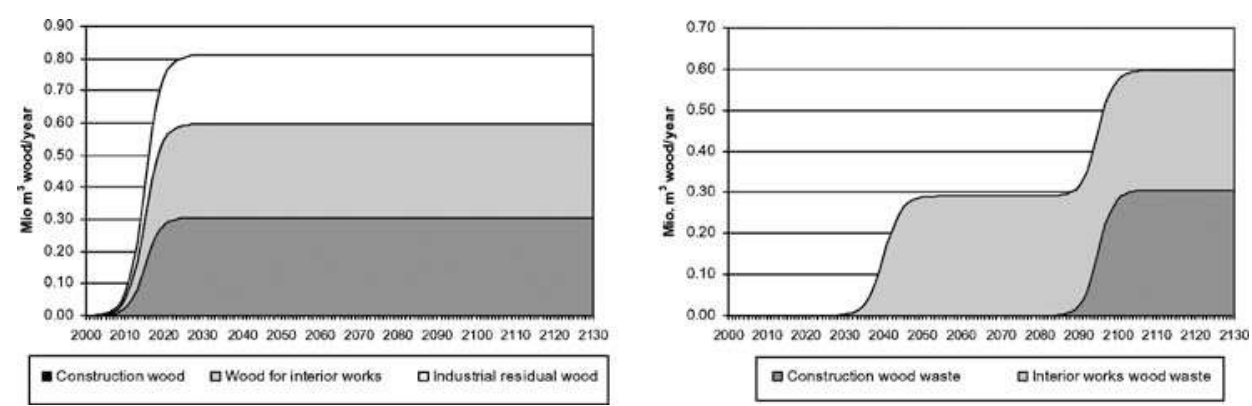

Figure 2. Increased use of wood flows (left) and waste wood flows (right) in the years 2000 to 2130 (cumulated data).

3.54 Mio $\mathrm{m}^{3} /$ annum in the year 2030 . This additional use of $0.81 \mathrm{Mio}^{3} / \mathrm{annum}$ is assumed to constantly run up to the year 2120 .

Figure 2 (left) illustrates the increased use of wood for the years 2000-2130. These wood quantities are attributed to the most relevant building elements such as roofs, exterior walls, interior walls, ceilings, floorings, etc. based on a Swiss market study on the current wood application potential in buildings (BUWAL, 1996). Table II shows the distribution of the $0.81 \mathrm{Mio}^{3}$ to the different wood products. For the years between 2000 and 2030, the input wood is distributed to the different wood products according to this relative share stated in Table II.

With these wood quantities, the market potential for wood used for roofing or for furnishing is almost reached with a market share of about $80 \%$ (own calculations based on BUWAL, 1996).

TABLE II

Distribution of the $0.81 \mathrm{Mio}^{3}$ additional wood to the different wood products, including residual wood (based on BUWAL (1996) and modelling assumptions)

\begin{tabular}{lrlr}
\hline Building element construction & $\mathrm{m}^{3}$ & Interior works & \multicolumn{1}{c}{$\mathrm{m}^{3}$} \\
\hline Laminated timber board & 70,298 & Profiled board spruce & 92,868 \\
Gluelam pillar & 1,054 & Staircase oak & 2,955 \\
Ceiling out of wooden beams & 154,145 & Three-layered parquet & 62,989 \\
Wood fibre insulation panel & 10,783 & Wood panels, rough, +supporting bars & 37,382 \\
Unlined joist construction & 53,275 & Doorframe, particleboard & 52,322 \\
Wood palisade (pile wall) & 15,423 & Furniture, particleboard & 33,930 \\
& & Total construction & 304,977 \\
& & Total interior works & 282,446 \\
& & Residual wood & 222,577 \\
& & Total & 810,000
\end{tabular}


Figure 2 also shows the respective waste wood flows, assuming an average service life of 80 years for constructive wood products and 25 years for wood used for interior works.

Swiss forests would be able to supply the additional wood quantities. According to the National Inventory of Forests (Brassel and Brändli, 1999), annual growth lies around $10 \mathrm{Mio}^{3}$ of wood. About $\frac{3}{4}$ or $7.5 \mathrm{Mio} \mathrm{m}^{3}$ are considered as usable wood. If one compares the actual and projected future wood consumption, Swiss forests would thus be able to satisfy the additional wood demand without any imports (see Hofer et al., 2002a; based on Brassel and Brändli, 1999).

\subsection{LIFE CYCLE DATA AS THE BASIS OF THE SUBSTITUTION CALCULATIONS}

Substitution is considered as the use of wood products instead of 'conventional' (solid) building products or fossil fuels.

For the determination of products that will be affected by an increased use of wood, assumptions must be made on the substitution mechanism. Different substitution mechanisms are conceivable and can depend on the type of decision maker, the type of building or the type of intervention (new construction, renovation, etc.). For this study, the results of an extensive survey on wood and its applicability in buildings among builder-owners, architects and engineers are used to determine the 'conventional' products to be substituted for (Quetting et al., 1999; Wiegand and Quetting, 1999a,b). Table III provides an overview of the substituting products. A detailed description of the products considered in this study can be found in (Hofer et al., 2004b).

The whole products are considered. This means that wooden products can contain adhesives, paint or non-wooden parts such as steel; also conventional products can contain (small) amounts of wood (see also different weights and carbon contents in Table IV).

For the determination of the GHG emissions associated with production, use and disposal of the above-mentioned products, data generated by LCA is used (Hofer et al., 2002a based on Frischknecht et al., 1996; Künniger and Richter, 1997, 1998, 2000; Künniger et al., 2000, 2001; Richter and Gugerli, 1996; Werner et al., 2003; Werner and Richter, 1997, 2001; Werner et al., 1997). In LCA, all environmental impacts - emissions and resources consumption - of all life cycle stages from raw material extraction, production to their use phase and disposal are accounted for and assessed, including energy generation and transports. Such LCA is commonly conducted according to the series of standards ISO 14'040ff.

To separate emissions within Switzerland from emission occurring abroad, a dominance analysis was conducted for each of the life cycle inventories to determine the most significant processes. Knowledge of the production patterns, importexport statistics, inquiries with industrial sector representatives, etc. is used to attribute these processes to the categories 'emissions in $\mathrm{CH}^{\prime}$ ' and 'emissions abroad'. 
TABLE III

Overview on the wooden building products and their substitutes (based on Quetting et al., 1999; Wiegand and Quetting, 1999a,b)

\begin{tabular}{|c|c|c|}
\hline Building element & Wood elements/products & Competing product/substitute \\
\hline \multicolumn{3}{|l|}{ Construction } \\
\hline Exterior wall & Laminated timber board & Two-layered brick wall \\
\hline Pillar & Gluelam pillar & Steel pillar \\
\hline Ceiling & Ceiling of wood beams & Ceiling of reinforced concrete \\
\hline Insulation & Wood fibre insulation panel ${ }^{\mathrm{a}}$ & Mineral wool $^{\mathrm{b}}$ \\
\hline Roofing & Unlined joist construction & Porous concrete pitched roof \\
\hline Underground engineering & Wood palisade (pile work) & Concrete palisade \\
\hline \multicolumn{3}{|l|}{ Interior works } \\
\hline $\begin{array}{l}\text { Coverings of ceilings } \\
\text { and walls }\end{array}$ & Profiled board, spruce & Interior plasterwork \\
\hline Staircase & Wooden staircase, oak & Ready-made concrete staircase \\
\hline Flooring & Three-layered parquet flooring & Ceramic tiles, enamelled \\
\hline Facade & $\begin{array}{l}\text { Wood panels rough including } \\
\text { supporting bars }{ }^{\mathrm{a}}\end{array}$ & Exterior plasterwork $^{\mathrm{b}}$ \\
\hline Furnishing & Doorframe, particleboard & Doorframe, steel \\
\hline Furniture & Wood furniture, particleboard & Steel furniture \\
\hline
\end{tabular}

an a laminated timber board construction.

${ }^{\mathrm{b}}$ In a two-layered brick wall.

Further, it is assumed that exclusively Swiss wood is used and that primary production processes for wood products are located in Switzerland (see Section 2.2); additives or fuels etc. can be imported. For each life cycle inventory, more than $95 \%$ of the emissions are attributed to the two data categories; the rest is accounted for as Swiss emissions.

The GHG effects are indicated in $\mathrm{CO}_{2}$-equivalent. This means that all GHG emissions are weighted by the greenhouse gas potential in relation to $\mathrm{CO}_{2}$ (IPCC, 1996). For the products made out of wood, the $\mathrm{CO}_{2}$ sequestered during photosynthesis enters the calculations as a negative data due to the withdrawal of $\mathrm{CO}_{2}$ from the atmosphere. This $\mathrm{CO}_{2}$ is released again during incineration or biological decomposition at the end of the product life cycle.

It is assumed that by using an additional wood product, the production, use and disposal of a substitute is avoided (-substitute + wood product). A negative sign of the result of this GHG calculation means that by using a wood product instead of its substitute, GHG emissions are avoided; a positive sign indicates that the (fossil) GHG emissions during the life cycle of the wood product are higher than the ones of the substitute (for product-specific data, see Table IV).

For the determination of the substitution effect, the current import-export patterns are taken into account (Hofer et al., 2002b). 
TABLE IV

Product-specific GHG emissions (excluding renewable $\mathrm{CO}_{2}$-emissions), carbon pool capacity and weight of the wood products and their substitutes under study, taking into account national boundaries; import-export relations of final or semi-finished products are considered (Hofer et al., 2002a based on Frischknecht et al., 1996; Künniger and Richter, 1997, 1998, 2000; Künniger et al., 2000, 2001; Richter and Gugerli, 1996; Werner et al., 1997, 2003; Werner and Richter, 1997, 2001)

\begin{tabular}{|c|c|c|c|c|c|c|c|c|}
\hline & & $\begin{array}{l}\text { Fossil fuel } \\
\text { emissions } \\
\mathrm{CH}\left(\mathrm{kg} \mathrm{CO}{ }_{2-}^{-}\right. \\
\text {equivalent) }\end{array}$ & $\begin{array}{l}\text { Fossil fuel } \\
\text { emissions } \\
\text { abroad (kg CO } \text { CO }_{2}- \\
\text { equivalent) }\end{array}$ & $\begin{array}{l}\text { Fossil fuel } \\
\text { emissions } \\
\text { total (kg CO}{ }_{2-} \\
\text { equivalent) }\end{array}$ & $\begin{array}{l}\text { Carbon } \\
\text { content } \\
\left(\mathrm{kg} \mathrm{CO}_{2-}\right. \\
\text { equivalent })\end{array}$ & $\begin{array}{l}\text { Weight } \\
\text { product } \\
(+ \text { repair }) \\
(\mathrm{kg})\end{array}$ & $\begin{array}{l}\text { Weight } \\
\text { wood } \\
(u=12 \%) \\
(\mathrm{kg})\end{array}$ & $\begin{array}{l}\text { Weight } \\
\text { wood } \\
(u=0 \%) \\
(\mathrm{kg})\end{array}$ \\
\hline \multirow[t]{3}{*}{ Laminated timber board $\left(\mathrm{m}^{2}\right)$} & Production & 16.27 & 13.72 & 30.00 & -121.03 & 95.9 & 74.0 & 66.1 \\
\hline & Disposal & 1.15 & 0.96 & 2.11 & 121.03 & & & \\
\hline & Total & 17.42 & 14.68 & 32.11 & & & & \\
\hline \multirow[t]{3}{*}{ Two-layered brick wall $\left(\mathrm{m}^{2}\right)$} & Production & 90.04 & 30.41 & & & & & \\
\hline & Disposal & 12.49 & 4.72 & & & & & \\
\hline & Total & 102.53 & 35.13 & & & & & \\
\hline \multirow[t]{3}{*}{ Gluelam pillar (piece) } & Production & 2.66 & 27.45 & 30.11 & -44.16 & 34.6 & 27.0 & 24.1 \\
\hline & Disposal & 0.40 & 0.32 & 0.72 & 44.16 & & & \\
\hline & Total & 3.07 & 27.76 & 30.83 & & & & \\
\hline \multirow[t]{3}{*}{ Steel pillar (piece) } & Production & 0.70 & 84.76 & & & 37.1 & & \\
\hline & Disposal & & & & & & & \\
\hline & Total & 0.70 & 84.76 & & & & & \\
\hline \multirow[t]{3}{*}{ Ceiling of wood beams $\left(\mathrm{m}^{2}\right)$} & Production & 23.58 & 26.22 & 49.80 & -92.24 & 188.3 & 56.4 & 50.4 \\
\hline & Disposal & 4.07 & 1.88 & 5.94 & 92.24 & & & \\
\hline & Total & 27.64 & 28.10 & 55.74 & & & & \\
\hline \multirow[t]{3}{*}{ Ceiling of reinforced concrete $\left(\mathrm{m}^{2}\right)$} & Production & 76.85 & 30.66 & & & 640.1 & & \\
\hline & Disposal & 67.30 & 18.83 & & & & & \\
\hline & Total & 144.15 & 49.49 & & & & & \\
\hline
\end{tabular}




\begin{tabular}{|c|c|c|c|c|c|c|c|c|}
\hline \multicolumn{9}{|c|}{$\begin{array}{l}\text { TABLE IV } \\
\text { (Continued) }\end{array}$} \\
\hline & & $\begin{array}{l}\text { Fossil fuel } \\
\text { emissions } \\
\mathrm{CH} \text { (kg CO } \mathrm{CO}_{2-} \\
\text { equivalent) }\end{array}$ & $\begin{array}{l}\text { Fossil fuel } \\
\text { emissions } \\
\text { abroad (kg } \mathrm{CO}_{2-} \\
\text { equivalent) }\end{array}$ & $\begin{array}{l}\text { Fossil fuel } \\
\text { emissions } \\
\text { total (kg CO} \mathrm{CO}_{2}- \\
\text { equivalent) }\end{array}$ & $\begin{array}{l}\text { Carbon } \\
\text { content } \\
\text { (kg CO} 2^{-} \\
\text {equivalent) }\end{array}$ & $\begin{array}{l}\text { Weight } \\
\text { product } \\
\text { (+repair) } \\
(\mathrm{kg})\end{array}$ & $\begin{array}{l}\text { Weight } \\
\text { wood } \\
(u=12 \%) \\
(\mathrm{kg})\end{array}$ & $\begin{array}{l}\text { Weight } \\
\text { wood } \\
(u=0 \%) \\
(\mathrm{kg})\end{array}$ \\
\hline \multirow[t]{3}{*}{ Wood fibre insulation panel $\left(\mathrm{m}^{2}\right)$} & Production & 12.04 & 3.81 & 15.85 & -52.50 & 32.1 & 32.1 & 28.7 \\
\hline & Disposal & 0.47 & 0.37 & 0.85 & 52.50 & & & \\
\hline & Total & 12.51 & 4.18 & 16.69 & & & & \\
\hline \multirow[t]{3}{*}{ Mineral wool $\left(\mathrm{m}^{2}\right)$} & Production & 3.41 & 1.33 & & & 4.5 & & \\
\hline & Disposal & 0.21 & 0.07 & & & & & \\
\hline & Total & 3.61 & 1.40 & & & & & \\
\hline \multirow{3}{*}{ Unlined joist construction $\left(\mathrm{m}^{2}\right)$} & Production & 33.24 & 9.55 & 42.78 & -68.69 & 99.1 & 42.0 & 37.5 \\
\hline & Disposal & 2.64 & 1.07 & 3.71 & 68.69 & & & \\
\hline & Total & 35.88 & 10.62 & 46.50 & & & & \\
\hline \multirow[t]{3}{*}{ Porous concrete pitched roof $\left(\mathrm{m}^{2}\right)$} & Production & 34.65 & 55.23 & 89.88 & -15.37 & 170.4 & 9.4 & 8.4 \\
\hline & Disposal & 3.90 & 1.54 & 5.44 & 15.37 & & & \\
\hline & Total & 38.55 & 56.77 & 95.32 & & & & \\
\hline \multirow[t]{3}{*}{ Wood palisade $\left(\mathrm{m}^{2}\right)$} & Production & 18.78 & 102.27 & 121.05 & -699.75 & 443.7 & 427.8 & 382.0 \\
\hline & Disposal & 4.27 & 0.44 & 4.72 & 699.75 & & & \\
\hline & Total & 23.05 & 102.71 & 125.77 & & & & \\
\hline \multirow[t]{3}{*}{ Concrete palisade $\left(\mathrm{m}^{2}\right)$} & Production & 284.8 & 94.6 & 379.4 & & & & \\
\hline & Disposal & 21.1 & 3.8 & 24.8 & & & & \\
\hline & Total & 305.9 & 98.4 & 404.3 & & & & \\
\hline \multirow[t]{3}{*}{ Profiled board spruce $\left(\mathrm{m}^{2}\right)$} & Production & 0.2 & 0.3 & 0.5 & -10.6 & 6.5 & 6.5 & 5.8 \\
\hline & Disposal & 0.1 & 0.1 & 0.2 & 10.6 & & & \\
\hline & Total & 0.3 & 0.5 & 0.8 & & & & \\
\hline
\end{tabular}


TABLE IV

(Continued)

\begin{tabular}{|c|c|c|c|c|c|c|c|c|}
\hline & & $\begin{array}{l}\text { Fossil fuel } \\
\text { emissions } \\
\mathrm{CH}\left(\mathrm{kg} \mathrm{CO} \mathrm{CO}^{-}\right. \\
\text {equivalent) }\end{array}$ & $\begin{array}{l}\text { Fossil fuel } \\
\text { emissions } \\
\text { abroad (kg CO} \text { CO }^{-} \\
\text {equivalent) }\end{array}$ & $\begin{array}{l}\text { Fossil fuel } \\
\text { emissions } \\
\text { total (kg CO} \mathrm{CO}_{2}- \\
\text { equivalent) }\end{array}$ & $\begin{array}{l}\text { Carbon } \\
\text { content } \\
\text { (kg CO} 2^{-} \\
\text {equivalent) }\end{array}$ & $\begin{array}{l}\text { Weight } \\
\text { product } \\
\text { (+repair) } \\
(\mathrm{kg})\end{array}$ & $\begin{array}{l}\text { Weight } \\
\text { wood } \\
(u=12 \%) \\
(\mathrm{kg})\end{array}$ & $\begin{array}{l}\text { Weight } \\
\text { wood } \\
(u=0 \%) \\
(\mathrm{kg})\end{array}$ \\
\hline \multirow[t]{3}{*}{ Interior plasterwork $\left(\mathrm{m}^{2}\right)$} & Production & 3.7 & 6.6 & 10.3 & & & & \\
\hline & Disposal & 1.1 & 0.4 & 1.5 & & & & \\
\hline & Total & 4.8 & 7.0 & 11.8 & & & & \\
\hline Wooden staircase, oak $\left(\mathrm{m}^{2}\right)$ & Total & 2.19 & 6.01 & 8.20 & & & & \\
\hline \multirow[t]{3}{*}{ Ready-made concrete staircase (piece) } & Production & 29.24 & 50.11 & & & & & \\
\hline & Disposal & 21.50 & 6.07 & & & & & \\
\hline & Total & 50.74 & 56.18 & & & & & \\
\hline Three-layered parquet flooring $\left(\mathrm{m}^{2}\right)$ & Production & 3.15 & 3.45 & 6.60 & -15.03 & 12.5 & 9.2 & 8.2 \\
\hline Ceramic tiles, enamelled $\left(\mathrm{m}^{2}\right)$ & Total & 1.79 & 22.09 & & & & & \\
\hline \multirow{3}{*}{$\begin{array}{l}\text { Wood panels, rough, }+ \text { supporting } \\
\text { strips }\left(\mathrm{m}^{2}\right)\end{array}$} & Production & 0.44 & -0.33 & 0.11 & -18.81 & 11.6 & 11.5 & 10.3 \\
\hline & Disposal & 0.20 & 0.22 & 0.42 & 18.81 & & & \\
\hline & Total & 0.64 & -0.11 & 0.53 & & & & \\
\hline
\end{tabular}

(Continued on next page) 


\begin{tabular}{|c|c|c|c|c|c|c|c|c|}
\hline & & $\begin{array}{l}\text { Fossil fuel } \\
\text { emissions } \\
\mathrm{CH}\left(\mathrm{kg} \mathrm{CO}{ }_{2-}^{-}\right. \\
\text {equivalent) }\end{array}$ & $\begin{array}{l}\text { Fossil fuel } \\
\text { emissions } \\
\text { abroad (kg } \mathrm{CO}_{2-} \\
\text { equivalent) }\end{array}$ & $\begin{array}{l}\text { Fossil fuel } \\
\text { emissions } \\
\text { total (kg CO}{ }_{2-}^{-} \\
\text {equivalent) }\end{array}$ & $\begin{array}{l}\text { Carbon } \\
\text { content } \\
\left(\mathrm{kg} \mathrm{CO}_{2^{-}}\right. \\
\text {equivalent })\end{array}$ & $\begin{array}{l}\text { Weight } \\
\text { product } \\
(+ \text { repair }) \\
(\mathrm{kg})\end{array}$ & $\begin{array}{l}\text { Weight } \\
\text { wood } \\
(u=12 \%) \\
(\mathrm{kg})\end{array}$ & $\begin{array}{l}\text { Weight } \\
\text { wood } \\
(u=0 \%) \\
(\mathrm{kg})\end{array}$ \\
\hline \multirow[t]{3}{*}{ Exterior plasterwork $\left(\mathrm{m}^{2}\right)$} & Production & 7.96 & 14.07 & & & $45(+45)$ & & \\
\hline & Disposal & 2.39 & 0.96 & & & & & \\
\hline & Total & 10.35 & 15.03 & & & & & \\
\hline \multirow[t]{3}{*}{ Doorframe, particleboard (piece) } & Production & 21.22 & 33.38 & 54.60 & -26.84 & $20(+20)$ & 16.4 & 14.7 \\
\hline & Disposal & 0.98 & 0.85 & 1.83 & 26.84 & & & \\
\hline & Total & 22.20 & 34.23 & 56.43 & & & & \\
\hline \multirow[t]{3}{*}{ Doorframe, steel (piece) } & Production & 19.66 & 74.02 & & & 90.0 & & \\
\hline & Disposal & 3.40 & 0.00 & & & & & \\
\hline & Total & 23.06 & 74.02 & & & & & \\
\hline \multirow[t]{3}{*}{ Wood furniture, particleboard (piece) } & Production & 16.25 & 24.93 & 41.18 & -26.84 & $20(+20)$ & 16.4 & 14.7 \\
\hline & Disposal & 0.98 & 0.85 & 1.83 & 26.84 & & & \\
\hline & Total & 17.23 & 25.78 & 43.01 & & & & \\
\hline \multirow[t]{3}{*}{ Steel furniture (piece) } & Production & 7.54 & 63.45 & & & 18.0 & & \\
\hline & Disposal & 0.00 & 0.00 & & & & & \\
\hline & Total & 7.54 & 63.45 & & & & & \\
\hline
\end{tabular}


The above-mentioned calculations are rather sensitive with regard to several assumptions: (a) the selected wood product representing a group of similar wood products, (b) the selected substitute representing a group of similar 'conventional' products, (c) the assumption that exactly this 'conventional' product substitutes for wood products, (d) assumptions on the electricity grid, and (e) the system boundaries and allocation procedures used in the individual LCAs (Werner and Scholz, 2002; Werner, in press). Nonetheless, attention was paid that the compared products are functionally equivalent and have the same service life.

\subsection{MATHEMATICAL MODEL}

The following formulas describe the cohort-model that was used for the study.

Total wood consumption $W_{\mathrm{T} j}$ in year $j$ is the sum of the wood consumed for construction, for interior works and the $36 \%$ residual wood that is caused during the processing of the respective amount of wood (leading to the factor 0.36 in Equations (4), (5) and (7). This factor represents long-time average residual wood production in Switzerland (BUWAL/BfS, 2000). The wood quantities used for construction and for interior works are predetermined as the scenario described in Section 2.2. Calculations are based on an average wood density of $500 \mathrm{~kg} / \mathrm{m}^{3}$ and a carbon content of $50 \%$.

$$
\begin{aligned}
W_{\mathrm{T} j} & =W_{\mathrm{C} j}+W_{\mathrm{I} j}+W_{\mathrm{R} j} \\
W_{\mathrm{C} j} & =\sum^{c} W_{c j} \\
W_{\mathrm{I} j} & =\sum^{i} W_{i j} \\
W_{\mathrm{R} j} & =0.36\left(W_{\mathrm{C} j}+W_{\mathrm{I} j}\right)
\end{aligned}
$$

with $W_{\mathrm{T} j}$ : total wood consumption in year $j[\mathrm{t}(u=0 \%)] ; W_{\mathrm{C} j}$ : total wood used for construction in year $j[\mathrm{t}(u=0 \%)] ; W_{c j}$ : wood used in a specific product $c$ used for construction in year $j[\mathrm{t}(u=0 \%)] ; W_{\mathrm{I} j}$ : total wood used for interior works in year $j[\mathrm{t}(u=0 \%)] ; W_{i j}$ : wood used for a specific product $i$ used for interior works in year $j[\mathrm{t}(u=0 \%)] ; W_{\mathrm{R} j}$ : total industrial residual wood in year $j[\mathrm{t}(u=0 \%)]$.

Formula 5 describes the GHG effects of an increased use of wood in the construction part for the year $j$ in Switzerland. It consists of the production emissions, the substitution effect of the avoided use of 'conventional' materials, the pool effect and the effect of the energetic substitution because of the thermal use of the residual wood. Further, GHG effects of the thermal use of post consumer wood that was used for construction in the year $j-80$ have to be considered, i.e. the substitution of fossil fuels as well as the emission of the wood-inherent carbon as reduction of the pool. This last term only applies after year 80 when the first products used for construction reach the end of their service life. 
Formula 6 describes GHG effects of an increased use of wood in the construction (i.e. the production emissions and substitution effects) abroad in year $j$.

The substitution effect of residual wood and post-consumer waste wood is considered to be equal.

$$
\begin{aligned}
C_{\mathrm{CCH} j}= & \sum^{c} W_{c j}\left(C_{\mathrm{PCH} c}-C_{\mathrm{SCH} c}-C_{\mathrm{P} c}\right)+0.36 W_{\mathrm{C} j} C_{\mathrm{R}} \\
& +\sum^{c} W_{c j-80}\left(C_{\mathrm{W}}+C_{\mathrm{P} c}\right)=\sum^{c} W_{c j}\left(C_{\mathrm{MCH} c}-C_{\mathrm{P} c}\right) \\
& +0.36 W_{\mathrm{C} j} C_{\mathrm{R}}+\sum^{c} W_{c j-80}\left(C_{\mathrm{W}}+C_{\mathrm{P} c}\right) \\
C_{\mathrm{CF} j}= & \sum^{c} W_{c j}\left(C_{\mathrm{PF} c}-C_{\mathrm{SF} c}\right)=\sum^{c} W_{c j} C_{\mathrm{MF} c} \quad \text { with } \\
W_{c j-80}= & 0 \text { if } j-80<0 \text { and } C_{\mathrm{R}}=C_{\mathrm{W}}
\end{aligned}
$$

with $C_{\mathrm{CCH}_{j}}$ : GHG effect of an increased use of wood in the construction in year $j$ in Switzerland [ $\mathrm{CO}_{2}$-equivalent]; $C_{\mathrm{CF}_{j}}$ : GHG effect of an increased use of wood in the construction in year $j$ abroad [ $\mathrm{tO}_{2}$-equivalent]; $C_{\mathrm{PCH} c}$ : production emissions related to the life cycle of the construction product $c$ in Switzerland (including fossil fuel emissions during disposal) [ $\mathrm{t} \mathrm{CO}_{2}$-equivalent/t wood $\left.(u=0 \%)\right] ; C_{\mathrm{SCH} c}$ : production emissions related to the life cycle of the substitute product for the wooden construction product $c$ in Switzerland (including fossil fuel emissions during disposal) [ $\left[\mathrm{CO}_{2}\right.$-equivalent/t wood $\left.(u=0 \%)\right] ; C_{\mathrm{PF}_{c}}$ : production emissions related to the life cycle of the construction product $c$ abroad (including fossil fuel emissions during disposal) [ $\mathrm{t} \mathrm{CO}_{2}$-equivalent/t wood $\left.(u=0 \%)\right] ; C_{\mathrm{SF} c}$ : production emissions related to the life cycle of the substitute product for the wooden construction product $c$ abroad (including fossil fuel emissions during disposal) $\left[\mathrm{t} \mathrm{CO}_{2}\right.$-equivalent/t wood $(u=0 \%)] ; C_{\mathrm{MCH} c}$ : net substitution effect when using a wood product $c$ instead of a functionally equivalent 'conventional' product in Switzerland (difference between the production and fossil disposal emissions over the life cycles of the wood product and the 'conventional' product) [ $\mathrm{t} \mathrm{CO}_{2}$-equivalent/t wood $\left.(u=0 \%)\right] ; C_{\mathrm{MF} c}$ : net substitution effect when using a wood product $c$ instead of a functionally equivalent 'conventional' product abroad (difference between the production and fossil disposal emissions over the life cycles of the wood product and the 'conventional' product) [ $\mathrm{t} \mathrm{CO}_{2}$-equivalent/t wood $\left.(u=0 \%)\right] ; C_{\mathrm{P} c}$ : pool effect of the wood product $c$, proportional to the wood content of the product $\left[\mathrm{t} \mathrm{CO}_{2}\right.$-equivalent/t wood $(u=0 \%)$ ]; $C_{\mathrm{R}}$ : substitution effect when using residual wood for the substitution of fossil fuels [ $\mathrm{tCO}_{2}$-equivalent/t wood $\left.(u=0 \%)\right] ; C_{\mathrm{W}}$ : substitution effect when using (post-consumer) waste wood for the substitution of fossil fuels [ $\mathrm{t} \mathrm{CO}_{2}$-equivalent/t wood $(u=0 \%)$ ].

The respective Formulas 7 and 8 are used for the GHG effect of an increased use of wood in interior works $C_{\mathrm{I} j}$ in year $j$. An average service life of 25 years is 
considered for the products used for interior works:

$$
\begin{aligned}
C_{\mathrm{ICH} j}= & \sum^{i} W_{i j}\left(C_{\mathrm{PCH} i}-C_{\mathrm{SCH} i}-C_{\mathrm{P} i}\right)+0.36 W_{\mathrm{Ij}} C_{\mathrm{R}} \\
& +\sum^{i} W_{i j-25}\left(C_{\mathrm{W}}+C_{\mathrm{P} i}\right)=\sum^{i} W_{i j}\left(C_{\mathrm{MCH} i}-C_{\mathrm{P} i}\right)+0.36 W_{\mathrm{I} j} C_{\mathrm{R}} \\
& +\sum^{i} W_{i j-25}\left(C_{\mathrm{W}}+C_{\mathrm{P} i}\right) \\
C_{\mathrm{IF} j}= & \sum^{i} W_{i j}\left(C_{\mathrm{PF} i}-C_{\mathrm{SF} i}\right)=\sum^{i} W_{i j} C_{\mathrm{MF} i} \quad \text { with } \\
W_{i j-25}= & 0 \text { if } j-25<0 \text { and } C_{\mathrm{R}}=C_{\mathrm{W}}
\end{aligned}
$$

with $C_{\mathrm{ICH} j}$ : GHG effect of an increased use of wood in interior works in year $j$ in Switzerland [ $\mathrm{t} \mathrm{CO}_{2}$-equivalent]; $C_{\mathrm{IF} j}$ : GHG effect of an increased use of wood in interior works in year $j$ abroad [ $\mathrm{t} \mathrm{CO}_{2}$-equivalent]; $C_{\mathrm{PCH} i}$ : production emissions related to the life cycle of the product $i$ used for interior works in Switzerland (including fossil fuel emissions during disposal) $\left[\mathrm{t} \mathrm{CO}_{2}\right.$-equivalent/t $\left.\operatorname{wood}(u=0 \%)\right]$; $C_{\mathrm{SCH} i}$ : production emissions related to the life cycle of the substitute for the wooden product $i$ used for interior works in Switzerland (including fossil fuel emissions during disposal) [ $\mathrm{t} \mathrm{CO}_{2}$-equivalent/t wood $\left.(u=0 \%)\right] ; C_{\mathrm{MCH} i}$ : net substitution effect when using a wood product $i$ instead of a functionally equivalent 'conventional' product in Switzerland (difference between the production and fossil disposal emissions over the life cycles of the wood product and the 'conventional' product) [ $t$ $\mathrm{CO}_{2}$-equivalent/t wood $\left.(u=0 \%)\right] ; C_{\mathrm{PF} i}$ : production emissions related to the life cycle of the product $i$ used for interior works abroad (including fossil fuel emissions during disposal) [ $\mathrm{t} \mathrm{CO}_{2}$-equivalent/t wood $\left.(u=0 \%)\right] ; C_{\mathrm{SF} i}$ : production emissions related to the life cycle of the substitute for the wooden product $i$ used for interior works abroad (including fossil fuel emissions during disposal) $\left[\mathrm{t} \mathrm{CO}_{2}\right.$-equivalent/t wood $(u=0 \%)] ; C_{\mathrm{MF} i}$ : net substitution effect when using a wood product $i$ instead of a functionally equivalent 'conventional' product abroad (difference between the production and fossil disposal emissions over the life cycles of the wood product and the 'conventional' product) [ $\mathrm{t} \mathrm{CO}_{2}$-equivalent/t wood $\left.(u=0 \%)\right] ; C_{\mathrm{P} i}$ : pool effect of the wood product $i$, proportional to the wood content of the product [ $\mathrm{t}$ $\mathrm{CO}_{2}$-equivalent/t wood $\left.(u=0 \%)\right] ; C_{\mathrm{R}}$ : substitution effect when using residual wood for the substitution of fossil fuels [ $\mathrm{t} \mathrm{CO}_{2}$-equivalent/t wood $\left.(u=0 \%)\right] ; C_{\mathrm{W}}$ : substitution effect when using (post-consumer) waste wood for the substitution of fossil fuels [ $\mathrm{t} \mathrm{CO}_{2}$-equivalent/t wood $\left.(u=0 \%)\right]$.

The data used to calculate Formulas 5-8 can be found in Table IV.

The GHG effects in Switzerland, abroad and in total in year $j$ are the respective sums of the GHG effects of the construction part and the interior works part in 
year $j$ :

$$
\begin{aligned}
C_{\mathrm{TCH} j} & =C_{\mathrm{CCH} j}+C_{\mathrm{ICH} j} \\
C_{\mathrm{TF} j} & =C_{\mathrm{CF} j}+C_{\mathrm{IF} j} \\
C_{\mathrm{T} j} & =C_{\mathrm{TCH} j}+C_{\mathrm{TF} j}
\end{aligned}
$$

with $C_{\mathrm{TCH} j}$ : GHG effects in Switzerland in year $j$ [t $\mathrm{CO}_{2}$-equivalent]; $C_{\mathrm{TF} j}$ : GHG effects abroad in year $j$ [ $\mathrm{t} \mathrm{CO}_{2}$-equivalent]; $C_{\mathrm{T} j}$ : total $\mathrm{GHG}$ effect in year $j\left[\mathrm{t} \mathrm{CO}_{2}\right.$ equivalent].

The cumulated GHG effects in Switzerland, abroad and in total until year $j$ are the sum of the respective GHG effects in the previous years including year $j$ :

$$
\begin{aligned}
K_{\mathrm{CH} j} & =\sum_{j=0}^{j} C_{\mathrm{TCH} j} \\
K_{\mathrm{F} j} & =\sum_{j=0}^{j} C_{\mathrm{TF} j} \\
K_{\mathrm{T} j} & =K_{\mathrm{CF} j}+K_{\mathrm{F} j}
\end{aligned}
$$

with $K_{\mathrm{CH} j}$ : cumulative $\mathrm{GHG}$ effects in Switzerland [t $\mathrm{CO}_{2}$-equivalent]; $K_{\mathrm{F} j}$ : cumulative $\mathrm{GHG}$ effects abroad [ $\mathrm{t} \mathrm{CO}_{2}$-equivalent]; $K_{\mathrm{T} j}$ : overall total cumulative $\mathrm{GHG}$ effect until year $j$ [ $\mathrm{tCO}_{2}$-equivalent $]$.

\section{Resulting GHG Dynamics}

\subsection{LONG-LIVING WOOD PRODUCTS AS CARBON POOL}

If the wood pool in the building stock is enlarged, a carbon pool is enlarged.

The average service life of construction wood of 80 years is assumed. This implies that with an increase of wood consumption until the year 2030, the wood pool in buildings will have reached steady state flow equilibrium in the year 2110 . From then on, the annual wood input is equal to the wood output. The dynamics of the building stock as carbon pool due to an increased use of wood is illustrated in Figure 3.

According to the assumed development of an increased use of wood, a strong enlargement of the carbon pool takes place from the year 2010 to the year 2030 $\left(-0.55 \mathrm{Miot} \mathrm{CO}_{2}\right.$ /annum as a maximum). From then on, the thermal use of first products of interior works at the end of their service life reduces the annual enlargement of the carbon pool. From the year 2050 onward, the annual enlargement of the pool stabilises at -0.28 Mio $\mathrm{CO}_{2}$ /annum until the moment when the thermal use of the additionally used construction wood starts. From the year 2110 onward, the wood inputs and outputs are in flow equilibrium; no more carbon is stored in this pool: the wood pool stabilises at $-30 \mathrm{Miot}^{\mathrm{CO}_{2}}$, which corresponds to an additional 


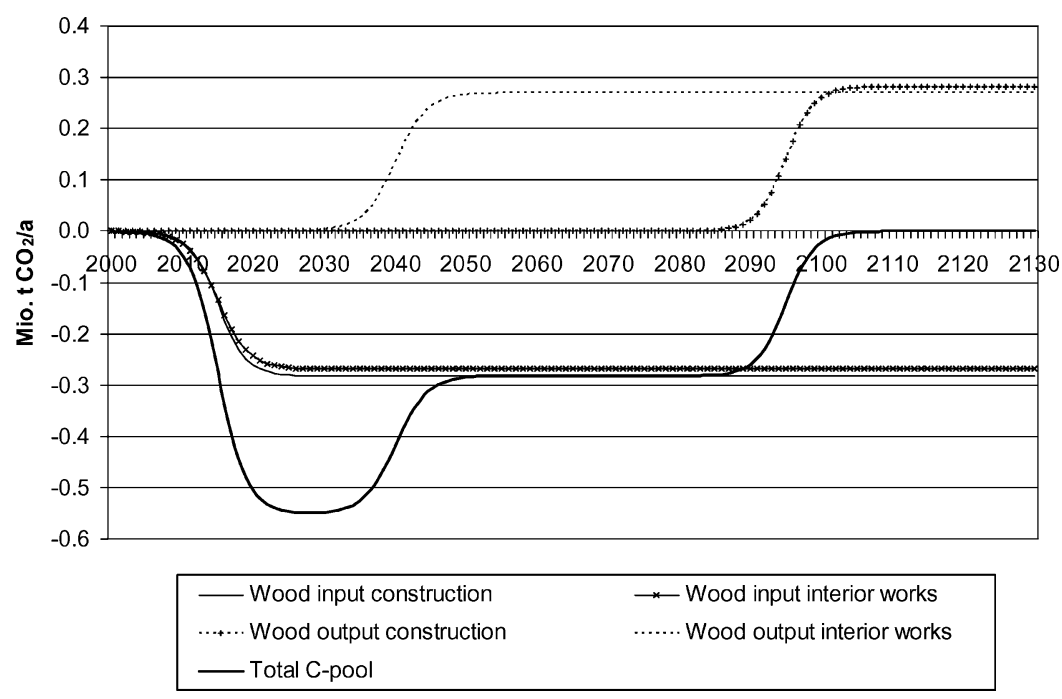

Figure 3. Dynamics of the building stock as carbon pool 2000-2130 (annual flows).

wood volume of $32 \mathrm{Mio}^{3}$ in the building stock. This pool potential corresponds to about $60 \%$ of the GHG emissions of Switzerland in 1 year; this potential will be reached by the year 2110 .

\subsection{PRODUCTION EMISSIONS AND SUBSTITUTION EFFECTS}

The relation between production and fossil disposal emissions of wood products and conventional products - and thus the possible substitution effect - as well as the possible carbon pool effect in wood products are product-dependent, as Figure 4 shows on an exemplary basis (for detailed data, see Table IV; also Pingoud and Lehtilä, 2002).

Figure 4 demonstrates that the (fossil) GHG emissions related to production and disposal of a wood product can surpass the carbon content of a finished wood product (example doorframes), but can also be considerably lower. Generally, the fossil GHG emissions from disposal can be neglected compared to the production emissions, except the ones for solid exterior walls (transport emissions because of weight!).

The production and disposal emissions of 'conventional' products tend to be higher than the ones caused by wood products (also Börjesson and Gustavsson, 2000; IPCC, 1996; Buchanan and Levine, 1999); the exception of the insulation material confirms this rule.

Also the locations of the relevant GHG emissions can differ. If 'conventional' products are produced abroad, an additional wood consumption in Switzerland will increase the national GHG inventory, as emissions occurring abroad will be 

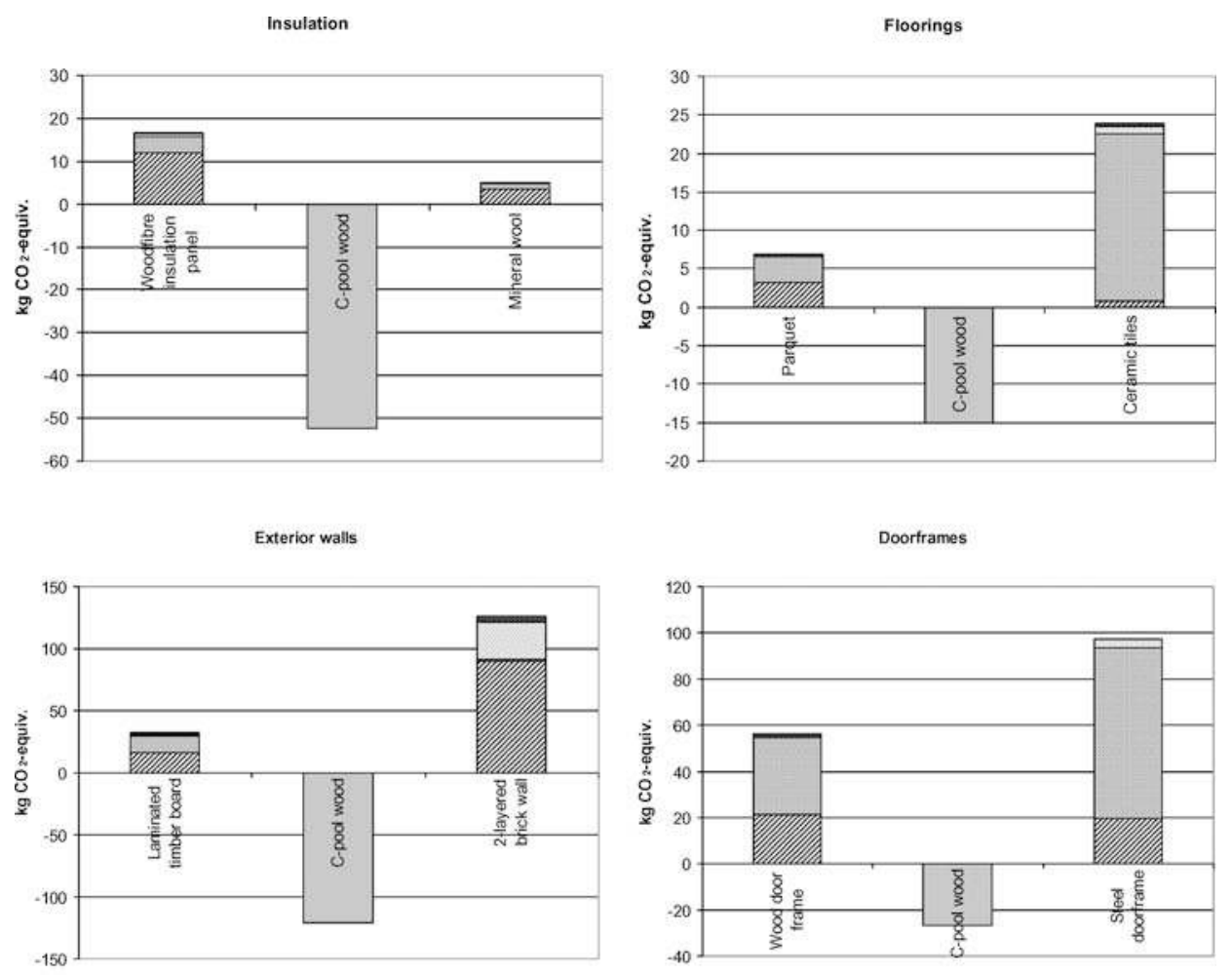

\section{$\square$ Production $\mathrm{CH} \quad \square$ Produktion abroad}

\section{बDisposal $\mathrm{CH} \quad$ : Disposal abroad}

Figure 4. Selected product-specific potential carbon pool capacities, production emissions and substitution effects, in Switzerland (CH) and abroad (Hofer et al., 2002a based on Frischknecht et al., 1996; Künniger and Richter, 1997, 1998, 2000; Künniger et al., 2000, 2001; Richter and Gugerli, 1996; Werner et al., 1997, 2003; Werner and Richter, 1997, 2001).

substituted for (example floorings). A similar mechanism can be observed with the products for interior works, as 'conventional' products are often made of GHGintense but imported steel; the associated emissions in Switzerland are relatively low. For construction materials on the contrary, the substitution for generally GHGintense, heavy and thus nationally produced, 'conventional' products of concrete or bricks will lead to a reduction of the GHG emissions in Switzerland.

In Figure 5, the resulting substitution potential of the considered wood products is illustrated. For this purpose the GHG emissions related to the production and disposal of a conventional product are subtracted from the fossil GHG emissions related to the production and disposal of the respective wood product. For this calculation, emissions occurring abroad are distinguished from emissions in Switzerland. Figure 5 shows that an increased use of wood for ceilings will lead to 


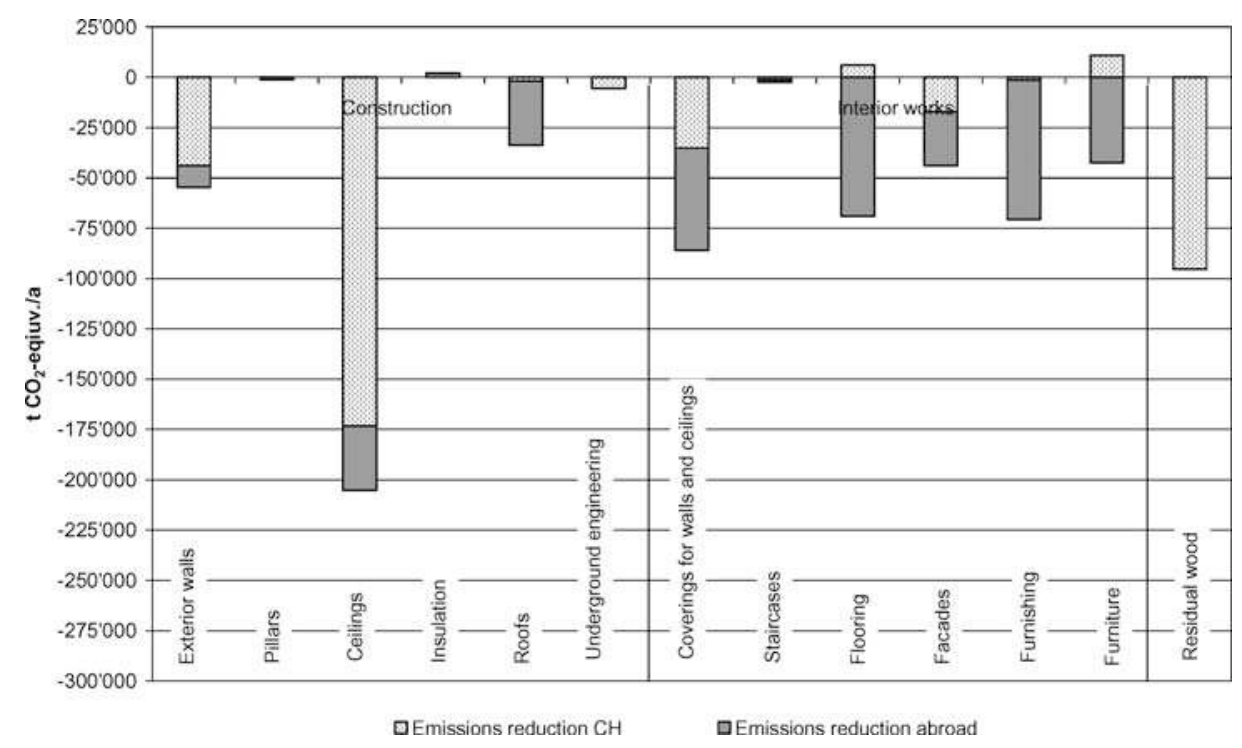

Figure 5. Substitution effects of different wood products due to an increased use of wood, in Switzerland $(\mathrm{CH})$ and abroad (+0.81 Mio $\mathrm{m}^{3}$ of wood) (Hofer et al., 2002a based on Künniger and Richter, 1997, 2000; Künniger et al., 2000, 2001; Richter and Gugerli, 1996; Werner et al., 1997, 2003; Werner and Richter, 1997, 2001).

the highest substitution effects - in a global perspective as well as in Switzerland. Given the currently low market share, wooden ceilings constitute a high potential for a GHG reducing use of wood. Further, a consequent and efficient thermal use of the additional residual wood in adequate furnaces to substitute for fossil fuels is of uppermost importance.

This result confirms the insight gained during the product-specific considerations: the substitution of GHG-intense 'conventional' (semi-finished) products for interior works provides a considerable GHG effect but the emissions are mainly avoided abroad. Contrary to that, the substitution of 'conventional' construction products provides a certain GHG emissions reduction potential in Switzerland, not only for the ceilings but also for exterior wood walls. In total, the production and disposal emissions of an increased use of wood ( $0.81 \mathrm{Mio}^{3} /$ annum) add up to

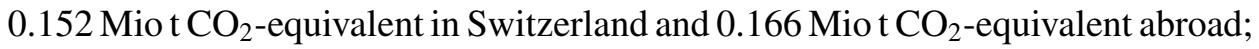
the respective material net substitution effects ( - substitute + wood product) add up to -0.261 Mio t $\mathrm{CO}_{2}$-equivalent in Switzerland and $-0.335 \mathrm{Miot} \mathrm{CO}_{2}$-equivalent abroad.

\subsection{ENERGETIC SUBSTITUTION EFFECTS}

The substitution capacity described in the previous section does not take into account the thermal utilisation of the residual and post-consumer waste wood. To 
TABLE V

Fuel inputs and GHG emissions of different installations for the generation of $1 \mathrm{TJ}$ usable energy (278 MWh) (Frischknecht et al., 1996; Frischknecht and Knechtle, 2000)

\begin{tabular}{lllll}
\hline Fuel & $\begin{array}{l}\text { Size of the } \\
\text { installation }(\mathrm{kW})\end{array}$ & $\begin{array}{l}\text { Fuel } \\
\text { quantity }(\mathrm{kg})\end{array}$ & $\begin{array}{l}\text { Fossil GHG emissions } \\
\left(\mathrm{kg} \mathrm{CO}_{2} \text {-equivalent }\right)\end{array}$ & $\begin{array}{l}\text { Difference } \\
\left(\mathrm{kg} \mathrm{CO}_{2} \text {-equivalent }\right)\end{array}$ \\
\hline Fuel oil & 100 & 27,200 & 91,100 & 88,090 \\
Logs & 100 & 100,000 & $3,010^{\mathrm{a}}$ & \\
\hline
\end{tabular}

${ }^{\mathrm{a}}$ Emissions from chainsaws, transports, etc.

calculate this effect, two (medium-sized) $100 \mathrm{~kW}$ incineration facilities fired with fuel oil as the most important fossil fuel in Switzerland and logs for the incineration of post-consumer wood are compared. This energetic substitution scenario is considered to be a reasonable assumption under actual Swiss conditions. However, a recent internal comparison of different types of burners for wood, gas and fuel oil revealed that the difference shown in Table $\mathrm{V}$ used to calculate the energetic substitution effects of an increased use of wood is rather conservative.

Around $0.21 \mathrm{Mio} \mathrm{m}^{3} /$ annum of the additionally used $0.81 \mathrm{Mio} \mathrm{m}^{3} /$ annum wood (from the year 2030 onward) end up as industrial residual wood and are used for the production of thermal energy. According to the calculations based on Table V, about $0.096 \mathrm{Miot} \mathrm{CO}_{2}$-equivalent/annum can be avoided because of the substitution of fossil fuels with the additional residual wood.

The remaining $0.6 \mathrm{Mio}^{3} / \mathrm{annum}$ or $300000 \mathrm{t}$ of wood/annum enter the building stock and can be used thermally at the end of the service life of the building elements. If all the wood that is additionally used in the building stock will be incinerated in adequate furnaces as post-consumer waste wood (as a hypothetical assumption to estimate the potential), an additional energetic substitution effect of $0.265 \mathrm{Miot}$ $\mathrm{CO}_{2}$-equivalent/annum can be achieved. This substitution effect is composed of the incineration of the products used for interior works (after a service life of 25 years) as well as of the products used for construction (after a service life of 80 years).

In total and over the whole life cycle of the wood products, emission reductions of 0.36 Miot $\mathrm{CO}_{2}$-equivalent can be achieved hypothetically with a consequent and efficient thermal utilisation of the generated residual and post-consumer waste wood as consequence of an additional use of $0.81 \mathrm{Mio}^{3}$ wood.

\subsection{GHG EMISSIONS DYNAMICS OF AN INCREASED USE OF WOOD}

The GHG emissions dynamics of an increased use of wood are relatively complex, as different effects with different temporal dynamics overlap. Figure 6 summarises the effects of a steadily increased use of wood up to $0.81 \mathrm{Mio}^{3} /$ annum from the year 2030 onward (see Section 2.2). 


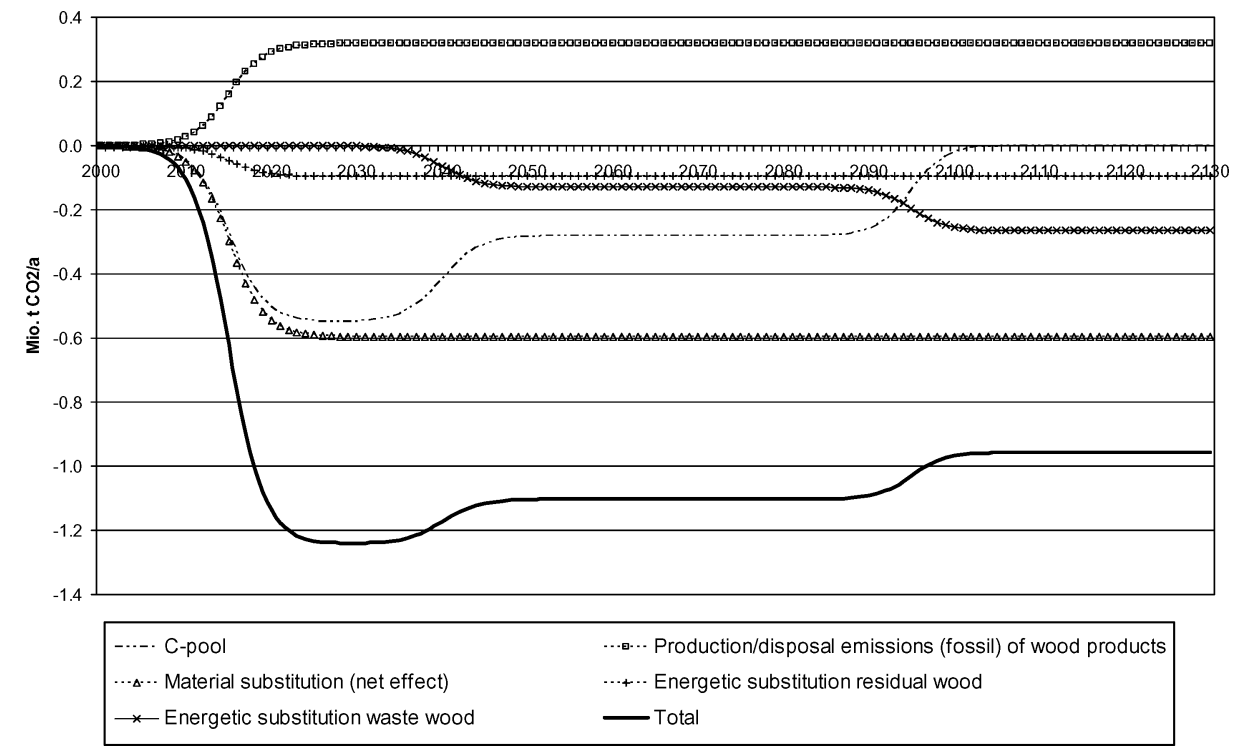

Figure 6. GHG dynamics of an increased use of wood (2000-2130).

Several points can be observed:

- The net GHG effects of the material substitution of $-0.6 \mathrm{Miot} \mathrm{CO}_{2}$ are more important than the (fossil) GHG emissions related to the production and disposal of the wood products of $0.3 \mathrm{Miot} \mathrm{CO}_{2}$;

- Only after about 150-200 years, the cumulated production and disposal emissions approximately equal the additionally stored carbon (see also Figure 8; this reconfirms a finding by Buchanan and Levine, 1999);

- The avoided (fossil) GHG emissions due to the thermal use of waste wood become more important than the thermal use of residual wood as soon as the thermal use of interior work waste wood reaches a constant level (2050);

- The substitution of fossil fuels as a consequence of the thermal use of residual and waste wood as well as the effects of the material substitution compensate by far the (fossil) GHG emissions from the production and disposal of the wood products. They are also more important than the effect on the carbon pool, especially in a long-term (this reconfirms findings of Börjesson and Gustavsson, 2000; IPCC, 1996; Marland and Marland, 1992);

- The stabilisation of the carbon pool is not compensated by the additional thermal use of waste wood and its substitution effect from the year 2090 onward;

- In the first years (2010 to the year 2035), the pool contributes around 60\% to the total GHG effect. The relative contribution of the pool diminishes over the years from the year 2030 onward;

- The largest GHG effect will be reached between year 2020 and 2030. 


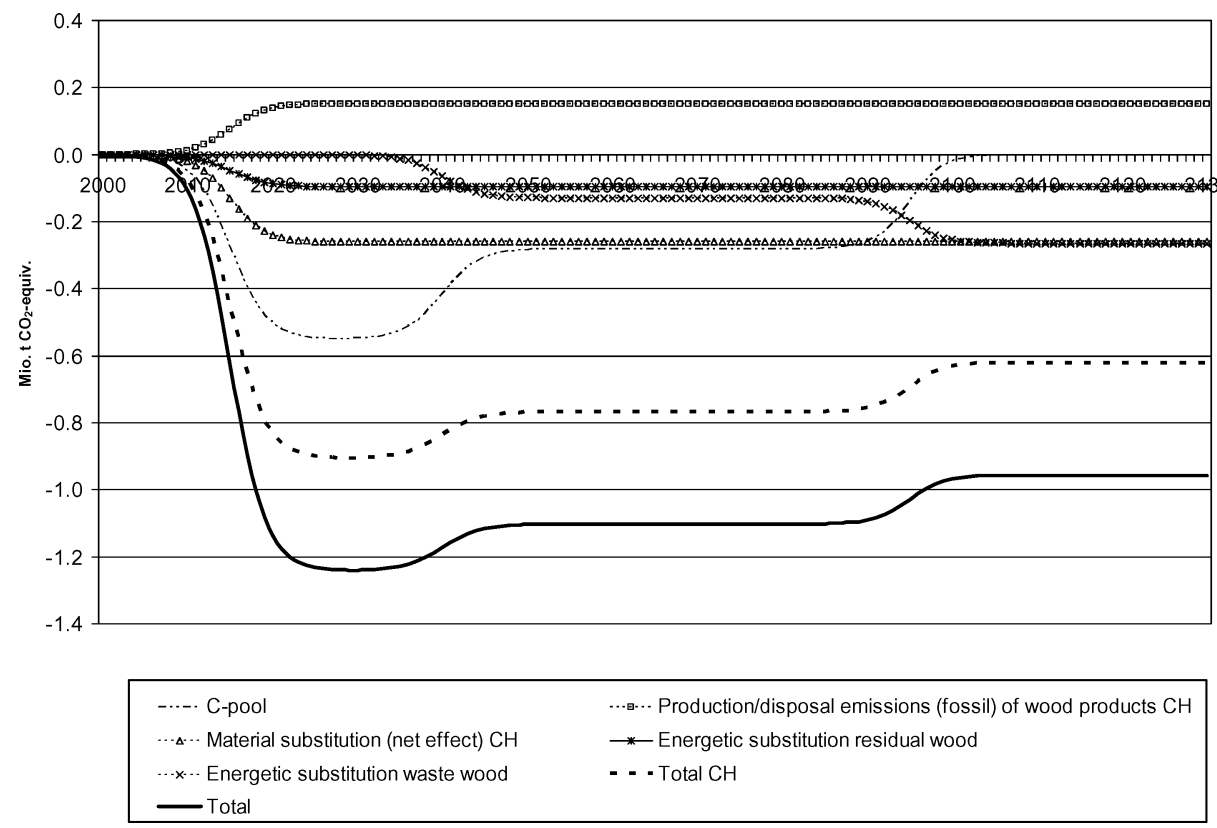

Figure 7. GHG dynamics of an increased use of wood in Switzerland (2000-2130).

\subsection{INFLUENCE OF SWISS NATIONAL BOUNDARIES}

Political decisions to increase the use of wood, as well as the inventory of the GHG emissions of Switzerland are made on national level. Thus, the GHG effects of an increased use of wood within Switzerland are of particular interest. The contributions of the different GHG-relevant mechanisms of an increased use of wood over time are depicted in Figure 7 (see also Figure 6 for comparison).

Figure 8 illustrates the cumulated GHG flows for the same period.

One can conclude that:

- The major part of the GHG effect as a consequence of an increased use of wood occurs in Switzerland;

- The dynamics of the GHG emissions in Switzerland correspond to the dynamics of the total flows (see Figure 8);

- In the steady state flow equilibrium (in the year 2100), the thermal use of waste wood is as relevant as the material substitution in Switzerland;

- During the first years, the fossil production emissions of the wood products are smaller than the pool effect; the relevance of the pool effect decreases in later years compared to the steadily increasing cumulated production emissions as well as compared to the total effect;

- A consequent and efficient use of post-consumer waste wood in adequate incinerators is a key strategy for the mitigation of the GHG relevance of 


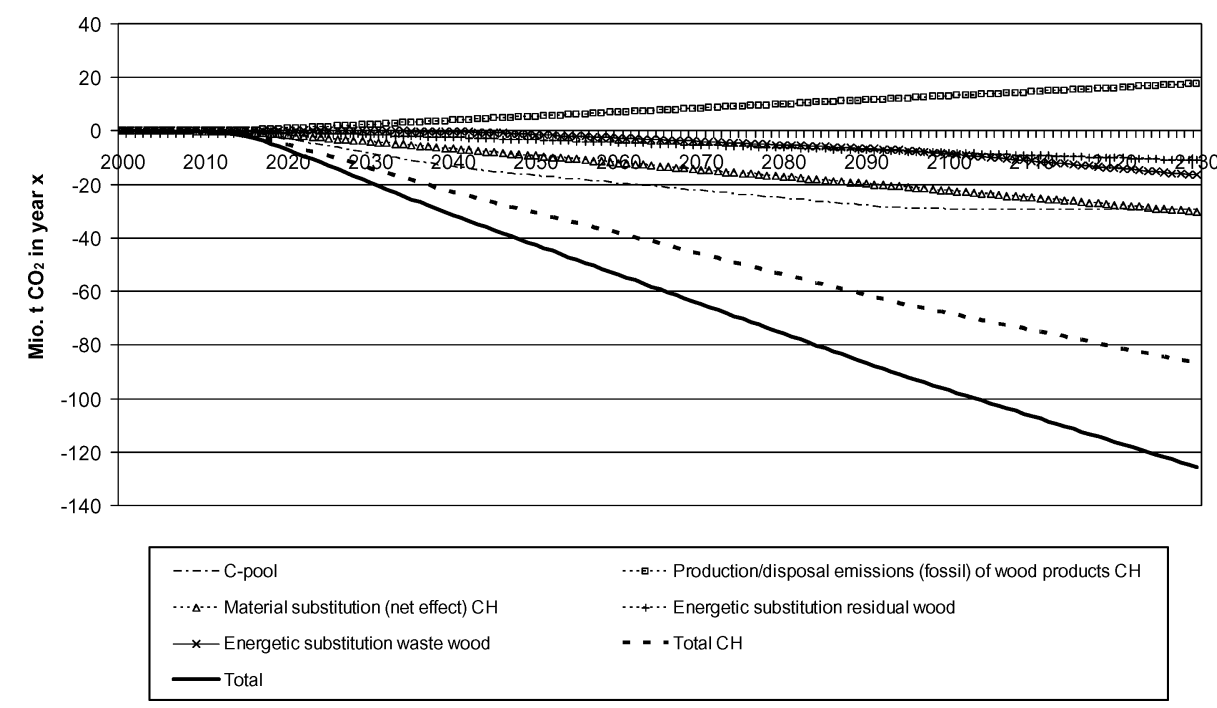

Figure 8. Cumulated GHG dynamics of an increased use of wood in Switzerland (2000-2130).

Switzerland - given the relation of residual wood and waste wood flows even more relevant than the thermal use of the residual wood.

An in-depth analysis of the (fossil) GHG emissions related to production and disposal as of the effects of the material substitution reveals that:

- About the same amount of GHG emissions related to production and disposal is released abroad and in Switzerland;

- The effect of the material substitution abroad corresponds more or less to the GHG effect achieved in Switzerland.

Figures 7 and 8 reveal that the relevance of the described effects changes over time. Table VI summarises the cumulated effects as well as their relative share of the total GHG effect in Switzerland for some (politically relevant) years.

Note for the interpretation of this table that emissions stated for earlier years cannot be added up with the stated emissions from later periods (cumulative data). The tendencies of the relative importance of individual effects as described above can easily be followed by looking at the percentages in a horizontal way.

Particular political relevance has the data for the year 2012, as this is the final year of the first commitment period of the Kyoto protocol. The relevance of the enlargement of the pool with a contribution of $-62 \%$ of the total effect in Switzerland is particularly noteworthy, followed by the effect of the material substitution with a relative effect of $-27 \%$. Of lower importance at this point in time is the effect of the thermal use of residual wood with $-11 \%$; post-consumer waste wood of the increased use of wood is still not available at that moment. These 'positive' effects 
TABLE VI

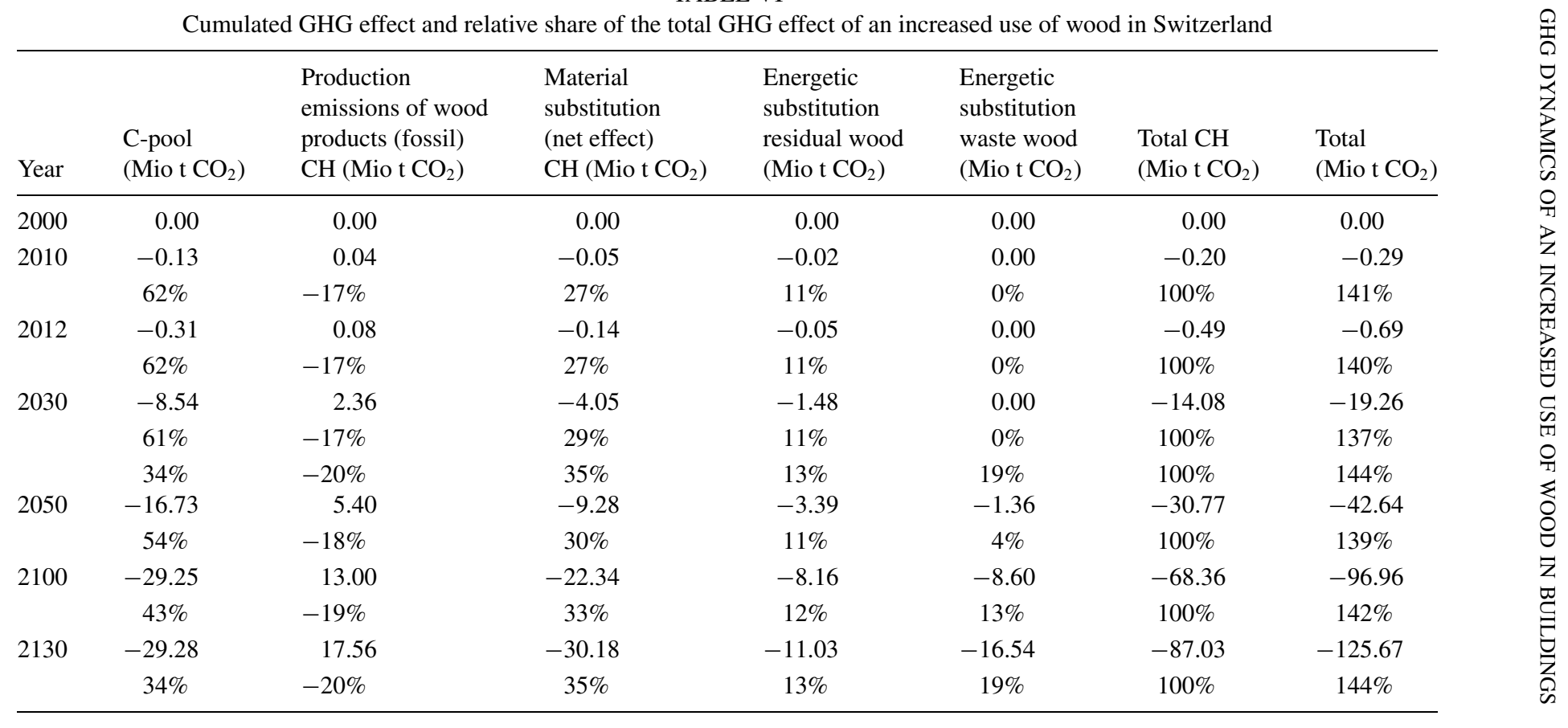


go along with product emissions of around $18 \%$ of the total effect of an increased use of wood in Switzerland.

If one considers the effect of an increased use of wood in the mirror of the reduction commitment in absolute terms, the following pictures arise. Assuming annual

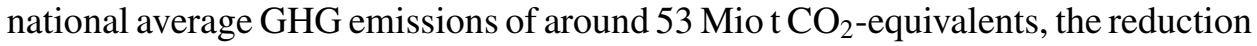
commitment of $8 \%$ over 5 years adds up to around $21 \mathrm{Miot} \mathrm{CO}_{2}$-equivalents. If this data is compared with the cumulated effect of an increased use of wood for the years 2008-2012, the total effect of 0.49 Mio $\mathrm{CO}_{2}$ is equivalent to about $2 \%$ of the reduction commitment. This low value is the consequence of the fact that the increased use of wood starts to become significant not earlier than the year 2010; the greatest effect of this wood use scenario develops between 2020 and 2030 (Figure 7).

This low relevance for the first commitment period should not be misinterpreted: an increased use of wood constitutes a reasonable measure to mitigate climate change-but only on a medium to long-term. This is illustrated in Figure 9, which shows how the GHG emissions of Switzerland would develop if the building elements were built of 'conventional' materials instead of wood.

In such scenario cumulated additional emissions of $0.22 \mathrm{Miot} \mathrm{CO}_{2}$-equivalents in Switzerland related to the use of 'conventional' products are facing cumulated emissions reductions and pool effects of around $-0.5 \mathrm{Miot} \mathrm{CO}_{2}$-equivalents because of an increased use of wood.

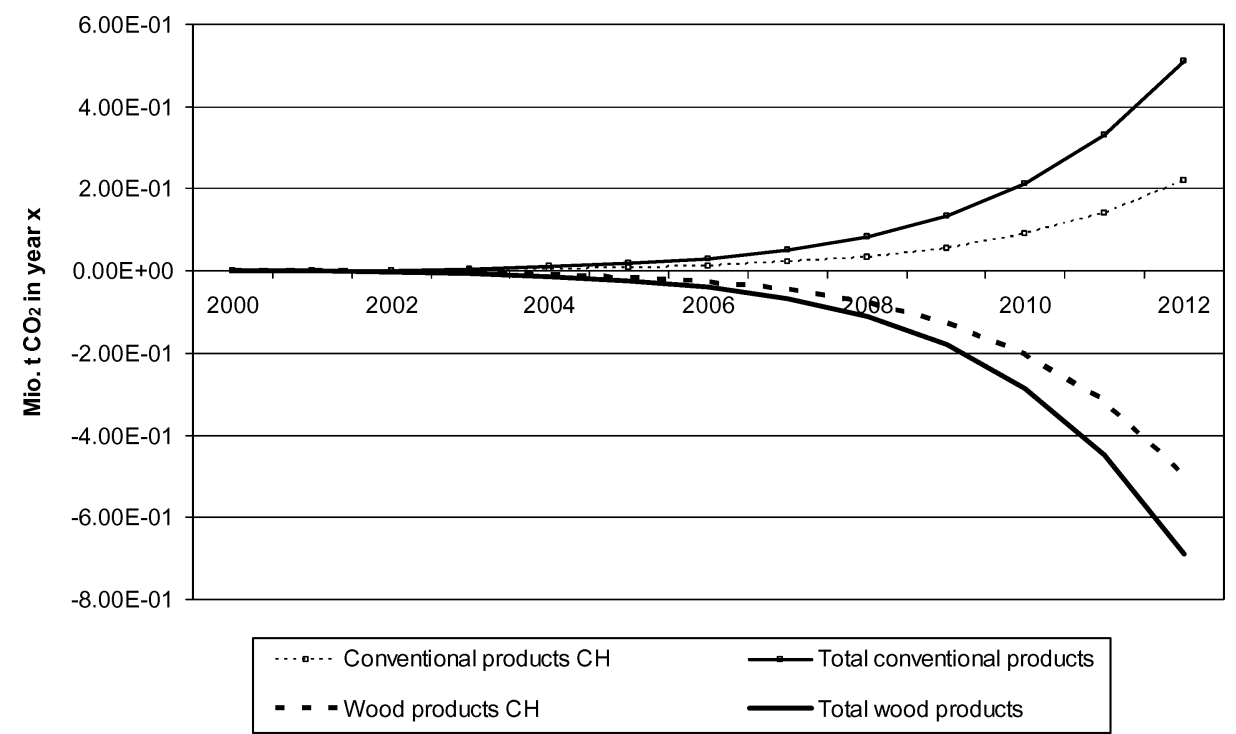

Figure 9. Scenario “"conventional” products instead of wood products' 2000-2012 (cumulated flows). 


\subsection{THESES ON THE INTERPLAY OF FORESTS AND WOOD PRODUCTS AS CARBON POOLS}

The principal aim of the investigation described above is to investigate the importance and dynamics of different GHG-related effects of an increased use of wood within the technosphere. One important effect of an increased use of wood was neglected on purpose: the decline of the carbon storage in the forests because of an increased wood extraction.

This interplay will be investigated in a future project where these results will be coupled to an investigation of the GHG effects of different forest management practices. Nonetheless, some general considerations on the pool dynamics of forests and wood products should be presented here.

The success of enlarging the pool of long-living wood products in the technosphere to achieve a major GHG abatement effect will depend on various variables:

- Up to twice as much biomass will be cut in the forests compared to the wood quantities that enter the building stock (conifers about $+25 \%$ Börjesson and Gustavsson, 2000). The forests will thus lose up to twice as much carbon than will be potentially stored in long-living wood products (excluding effects on the organic carbon soil content);

- The way in which the remaining wood in the forest is used will be a key factor with regard to the $\mathrm{CO}_{2}$ source effect of cutting trees. Substituting for fossil fuels with the surplus organic material seems the most promising strategy from a climate change perspective (Börjesson and Gustavsson, 2000; Marland and Schlamadinger, 1998). Nonetheless, site productivity should not be affected (Matthews et al., 1996);

- Mathematically, the results will depend much on the use of the forests in the scenario where only additional 'conventional' materials are used (Börjesson and Gustavsson, 2000; Marland and Schlamadinger, 1998);

- The overall pool effect will basically depend on the ratio between the growth rate of new trees and the service life of products (Fischlin, 1996; IPCC, 1997c);

- Negative overall pool effects ('source' effects) cannot be excluded from an increased use of wood - at least in short- to medium-term. Still, the size of the energetic and material substitution effects will justify an increased use of wood in any case.

\section{Conclusions}

An increased use of wood in the building sector can have relevant effects in terms of GHG emissions reductions on a medium-term. Substitution effects related to the thermal use of residual and post-consumer waste wood as well as effects related 
to the substitution of wood products for products made of 'conventional' materials contribute the most to the overall GHG effect. The carbon effect due to the enlargement of the pool of wood products should not be overestimated and might in fact be rather low. This effect is linked to a far larger decrease of the standing volume of trees (and thus carbon) in the forests and of soil carbon as a consequence of the harvesting, an effect that is compensated only very slowly by the re-growth of the forest. Given the relative importance of the energetic substitution effects, it is not surprising to see that the major part of the GHG effects occur in Switzerland. Still, a Swiss national strategy to mitigate climate change by an increased use of wood products should target wood products used for construction. Only for this group of wood products, the related material substitution effects occur within Switzerland, as energy-intense, locally produced heavy products such as concrete or bricks are substituted for. On the contrary, wood products used for interior works mostly substitute for imported products such as steel or ceramic tiles; the related substitution effect in Switzerland is low or even negative.

Concluding, three key elements of a Swiss strategy to mitigate climate change by an increased use of wood in buildings are summarised:

1. Efficient and effective thermal use of residual and post-consumer waste wood to substitute for fossil fuels;

2. Increased use of wood in construction;

3. Avoidance of collateral carbon emissions in the forests during harvesting (decrease of the carbon pool in trees and forest soil), i.e. the thermal utilisation of harvesting residues to substitute for fossil fuels.

Finally, it has to be stated that the GHG effects related to an increased use of wood in buildings are not sufficient to compensate the high GHG emissions in other sectors of the economy. Additional measures in those sectors - traffic for example - are necessary to meet future GHG reduction commitments of Switzerland.

\section{Acknowledgments}

This research was financed by the Swiss Agency of Environment, Forests and Landscape (BUWAL). We thank three anonymous reviewers for their constructive remarks.

\section{References}

Börjesson, P. and Gustavsson, L.: 2000, 'Greenhouse gas balances in building construction: Wood versus concrete from life-cycle and forest land-use perspectives', Energy Policy 28(9), 575-588.

Brassel, P. and Brändli, U. B. (eds.): 1999, 'Schweizerisches Landesforstinventar', Ergebnisse der Zweitaufnahme 1993-1995. Haupt, Bern, Stuttgart, Wien. 
Buchanan, A. H. and Honey, B. G.: 1994, 'Energy and carbon dioxide implications of building construction', Energy Build. 20, 205-217.

Buchanan, A. H. and Levine, S. B.: 1999, 'Wood-based building materials and atmospheric carbon emissions', Environ. Sci. Policy 2(6), 427-437.

BUWAL: 1996, 'Endverbrauch des Holzes in der Schweiz 1996', Umwelt-Materialien Nr. 94, Bundesamt für Umwelt, Wald und Landschaft (BUWAL), Bern.

BfS/BUWAL: 2000, 'Wald und Holz in der Schweiz; Jahrbuch 2000', Statistik der Schweiz, Bundesamt für Umwelt, Wald und Landschaft (BUWAL), Bundesamt für Statistik (BFS), Neuenburg.

Fischlin, A.: 1996, 'Conflicting objectives while maximising carbon sequestration by forests', in Forest Ecosystems, Forest Management and the Global Carbon Cycle, NATO ASI Series, Vol. I 40, Springer-Verlag, Berlin, Heidelberg, pp. 163-172.

Ford-Robertson, J.: 2003, 'Implications of harvested wood products accounting; analysis of issues raised by parties to the UNFCCC and development of a simple decay approach', MAF Technical Paper No: 2003/5, Ministry of Agriculture and Forestry, Wellington.

Frischknecht, R. and Knechtle, N.: 2000, Heizenergie aus Heizöl, Erdgas oder Holz? Schriftenreihe Umwelt SRU 315, Bundesamt für Bundesamt für Umwelt, Wald und Landschaft (BUWAL), Bern.

Frischknecht, R., Suter, P., Bollens, U., Bosshart, S., Ciot, M., Ciseri, L., Doka, G., Hischier, R., Martin, A., Dones, R., and Gantner, U.: 1996, 'Ökoinventare von Energiesystemen, Grundlagen für den ökologischen Vergleich von Energiesystemen und den Einbezug von Energiesystemen in Ökobilanzen für die Schweiz', 3. Aufl., Bundesamt für Energiewirtschaft (BEW/PSEL), Bern.

Hashimoto, S., Nose, M., Obara, T., and Moriguchi, Y.: 2002, 'Wood products: Potential carbon sequestration and impact on net carbon emissions of industrialized countries', Environ. Sci. Policy 5(2002), 183-193.

Hofer, P., Morf, L., Taverna, R., and Richter, K.: 2001, 'Speicherung von $\mathrm{CO}_{2}$ in Holzlagern im Zivilisationskreislauf und Emissionseffekte der Substitution bei gesteigerter Holzverwendung', GEO Partner, Zürich.

Hofer, P., Taverna, R., Richter, K., and Werner, F.: 2002a, 'Gebäudepark als Holzlager', GEO Partner, Zürich.

Hofer, P., Taverna, R., Richter, K., and Werner, F.: 2002b, 'Senkenleistung und Materialsubstitution beim Schweizer Gebäudepark im Hinblick auf die nationale Treibhausgasbilanz', GEO Partner, Zürich.

IPCC: 1996, Climate Change 1995; The Science of Climate Change, Cambridge University Press, published for the International Panel on Climate Change (IPCC), Cambridge.

IPCC (ed.): 1997a, Revised 1996 IPCC Guidelines for National Greenhouse Gas Inventories; Volume 1: Reporting Instructions.

IPCC (ed.): 1997b, Revised 1996 IPCC Guidelines for National Greenhouse Gas Inventories; Volume 2: Workbook.

IPCC (ed.): 1997c, Revised 1996 IPCC Guidelines for National Greenhouse Gas Inventories; Volume 3: Greenhouse Gas Inventory Reference Manual.

IPCC (ed.): 1998, 'Evaluating approaches for estimating net emissions of carbon dioxide from forest harvesting and wood products; meeting report, Dakar, Senegal, 5-7 May 1998', IPCC/OECD/IEA Programme on National Greenhouse Gas Inventories, Geneva.

IPCC (ed.): 2000, Land Use, Land-Use Change, and Forestry; A Special Report of the IPCC, Cambridge University Press, Cambridge.

IPCC: 2003, Good Practice Guidance For Land Use, Land-Use Change and Forestry, Institute for Global Environmental Strategies (IGES), Hayama.

Karjalainen, T.: 1996, 'Model computations on sequestration of carbon in managed forests and wood products under changing climatic conditions in Finland', J. Environ. Manage. 47(4), 311-328. 
Koch, P.: 1992, 'Wood versus nonwood materials in U.S. residential construction: Some energy related global implications', Forest Prod. J. 42(5), 31-42.

Künniger, T. and Richter, K.: 1997, 'Ökologischer Vergleich von Freileitungsmasten aus imprägniertem Holz, armiertem Beton und korrosionsgeschütztem Stahl', Eidg. Materialprüfungs- und Forschungsanstalt (Empa), Dübendorf.

Künniger, T. and Richter, K.: 1998, 'Ökologischer Vergleich von Eisenbahnschwellen in der Schweiz; Streckenschwellen aus vorgespanntem Beton, Profilstahl und teerölimprägniertem Buchenholz, Forschungs- und Arbeitsbericht 115/38', Eidg. Materialprüfungs- und Forschungsanstalt (Empa), Dübendorf.

Künniger, T. and Richter, K.: 2000, 'Ökobilanzen von Konstruktionen im Garten- und Landschaftsbau', Eidg. Materialprüfungs- und Forschungsanstalt (Empa), Dübendorf.

Künniger, T., Richter, K., and Werner, F.: 2000, ‘Ökobilanzdaten von Kies, Zement und Beton’, Eidg. Materialprüfungs- und Forschungsanstalt (Empa), Dübendorf.

Künniger, T., Werner, F., and Richter, K.: 2001, 'Ökologische Bewertung von Kies, Zement und Beton in der Schweiz (Kurzfassung)', Forschungs- und Arbeitsbericht 115/45, Schweizerische Materialprüfungs- und Forschungsanstalt (Empa), Dübendorf.

Lim, B., Brown, S., and Schlamadinger, B.: 1999, 'Carbon accounting for forest harvesting and wood products: Review and evaluation of different approaches', Environ. Sci. Policy 2, 207-216.

Liski, J., Pussinen, A., Pingoud, K., Mäkipää, R., and Karjalainen, T.: 2001, 'Which rotation length is favourable to mitigation of climate change', Can. J. Forest Res. 31, 2004-2013.

Marcea, R. I. and Lau, K. K.: 1992, 'Carbon dioxide implication of building materials', J. Forest Eng. 3(2), 37-43.

Marland, E. and Marland, G.: 2003, 'The treatment of long-lived, carbon-containing products in inventories of carbon dioxide emissions to the atmosphere', Environ. Sci. Policy 6(2), 139-152.

Marland, G. and Marland, S.: 1992, 'Should we store carbon in trees', Water Air Soil Pollut., Special Issue Natural Sinks of $\mathrm{CO}_{2}$ 64(1-2), 181-195.

Marland, G. and Schlamadinger, B.: 1998, 'Forests for carbon sequestration or fossil fuel substitution? A sensitivity analysis', Biomass Bioenergy 13(6), 389-397.

Matthews, R. W., Nabuurs, G.-J., Alexeyev, V., Birsey, R. A., Fischlin, A., Maclaren, J. P., Marland, G., and Price, D. T.: 1996, 'WG3 Summary: Evaluation the role of forest management and forest products in the carbon cycle', in Forest Ecosystems, Forest Management and the Global Carbon Cycle, NATO ASI Series, Vol. I 40, Springer-Verlag, Berlin, Heidelberg, pp. 293-301.

Micales, J. A. and Skog, K. E.: 1997, 'The decomposition of forest products in landfills', Int. Biodeterioration Biodegradation 39(2-3), 145-158.

Niles, J. and Schwarze, R.: 2001, 'The value of careful carbon accounting in wood products', Clim. Change 49(4), 371-376.

Pingoud, K. and Lehtilä, A.: 2002, 'Fossil carbon emissions associated with carbon flows of wood products', Mitigation and Adaptation Strategies for Global Change 7(1), 63-83.

Pingoud, K., Perälä, A. -L., and Pussinen, A.: 2001, 'Carbon dynamics in wood products', Mitigation and Adaptation Strategies for Global Change 6(2), 91-111.

Quetting, M., Wiegand, J., and Sell, J.: 1999, 'Tiefenerhebung zu Entscheidungsmotiven und zum Image von Holz im Hochbau in der Schweiz', Forschungs- und Arbeitsberichte 115/40, Eidg. Materialprüfungs- und Forschungsanstalt (Empa), Dübendorf.

Richter, K. and Gugerli, H.: 1996, 'Holz und Holzprodukte in vergleichenden Ökobilanzen', Holz als Roh- und Werkstoff 54, 225-231.

SBSTA/UNFCCC: 2001, FCCC/SBSTA/2001/Misc.1: Issues related to emissions from forest harvesting and wood products; Submission from Parties. Retrieved from http://UNFCCC.int/resource/ docs/2001/sbsta/misc01.pdf.

SBSTA/UNFCCC: 2003a, FCCC/SBSTA/2003/Misc.1/Add.1: Good practice guidance and other information on land use, land-use change and forestry; implications of harvested wood products 
accounting; Submission from Parties; Addendum. Retrieved from http://UNFCCC.int/resource/ docs/2003/sbsta/misc01a01.pdf.

SBSTA/UNFCCC: 2003b, FCCC/SBSTA/2003/Misc.1/Add.2: Good practice guidance and other information on land use, land-use change and forestry; implications of harvested wood products accounting; Submission from Parties; Addendum. Retrieved from http://UNFCCC.int/resource/ docs/2003/sbsta/misc01a02.pdf.

SBSTA/UNFCCC: 2003c, FCCC/SBSTA/2003/Misc.1: Good practice guidance and other information on land use, land-use change and forestry; implications of harvested wood products accounting; Submission from Parties. Retrieved from http://UNFCCC.int/resource/docs/2003/ sbsta/misc01.pdf.

Sedjo, R. A.: 1989, 'Forests to offset the greenhouse effect', J. Forest. 87, 12-15.

Sedjo, R. A.: 2002, 'Wood materials used as a means to reduce greenhouse gases (GHGS): An examination of wooden utility poles', Mitigation and Adaptation Strategies for Global Change 7, 191-200.

Skog, K. E. and Nicholson, G. A.: 1998, 'Carbon cycling through wood products: The role of wood and paper products in carbon Sequestration', Forest Prod. J. 48(7-8), 75-83.

Suzuki, M., Tatsuo, O., and Okada, K.: 1995, 'The estimation of energy consumption and $\mathrm{CO}_{2}$ emission due to housing construction in Japan', Energy Build. 22(165-169).

Thompson, D. A. and Matthews, R. W.: 1989, 'The storage of carbon in trees and timber', Forestry Commission Research Information Note 160, Edinburgh.

UNFCCC/TP: 2003, FCCC/TP/2003/7: Estimation, reporting and accounting of harvested wood products. Retrieved from http://UNFCCC.int/resource/docs/tp/tp0307.pdf.

Werner, F., Künniger, T., Althaus, H. -J., and Richter, K.: 2003, Life cycle inventories of wood as fuel and construction material, Duebendorf, November 2002. Ecoinvent-Report No. 9, Centre for life cycle inventories in the ETH domain, Duebendorf.

Werner, F. and Richter, K.: 1997, ‘Ökologische Untersuchung von Parkettfussböden’, Holz-Zbl. 123, 1759.

Werner, F. and Richter, K.: 2001, 'Lebenszyklusanalyse bei Fassaden', in Innovative Fassaden, Tagung Baden-Baden, 7. und 8. November 2001, VDI-Bericht 1642. VDI-Gesellschaft Bautechnik, Düsseldorf, 243-253.

Werner, F., Richter, K., Bosshart, S., and Frischknecht, R.: 1997, Ökologischer Vergleich von Innenbauteilen am Bsp. von Zargen aus Massivholz, Holzwerkstoff und Stahl. Empa/ETHForschungsbericht, Dübendorf, Zürich.

Werner, F. and Scholz, R. W.: 2002, 'Ambiguities in decision-oriented life cycle inventories; the role of mental models', Int. J. LCA 7(6), 330-338.

Werner, F.: in press, Ambiguities in Decision-Oriented Life Cycle Inventories; the Role of Mental Models and Values, Springer, Dordrecht.

Wiegand, J. and Quetting, M.: 1999a, 'Ergebnisse im Hochbau; Untersuchung über Entscheidungsmotive und Kenntnisse zu Holz', SAH Bulletin CSRB 3(1999), 13-29.

Wiegand, J. and Quetting, M.: 1999b, 'Ergebnisse im übrigen Bauwesen und im Bereich Möbel; Untersuchung über Entscheidungsmotive und Kenntnisse zu Holz', SAH Bulletin CSRB 3(1999), $30-35$.

Winjum, J. K., Brown, S., and Schlamadinger, B.: 1997, 'Forest harvests and wood products: Sources and sinks of atmospheric carbon dioxide', Forest Sci. 44, 271-284. 